SURFACE CATCHES OF MARINE DIATOMS AND DINOFLAGELLATES MADE BY.U.S.S. PIONEER BETWEEN SAN DIEGO AND SEATTLE IN 1923

BY

WINFRED EMORY ALLEN

\footnotetext{
Univeritit of California Publications in Zoology

Volume 26,-No. 12, pp. 243-248, plate 25
}

UNIVERSITY OF CALIFORNIA PRESS

BERKELEY, CALIFORNIA

$$
2^{d}{ }_{\text {Monograph }}^{1924}
$$




\section{UNIVERSITY OF CALIFORNIA PUBLICATIONS}

Note.-The University of Californila Publications are offered in exchange for the publications of learned societies and Institutions, universities, and Hibrarles. Complete lists of ail the publications of the University will be sent upon request. For sample copies, lists of pablications or other information, address the MANAGER OF THE UNIVERSIII PRES8, BERKELEY, CATIFORNIA, U. S. A. All matter sent in exchange should bo iddressed to THE EXCHANGE DEPARTMENT, UNIVERSITY LIBRARY, BERKEIEY, OAITFORNIA, U.S.A.

Agent for the series in American Archaeology and Ethnology, Botany, Geology, Physiology, and Zoology.

ZOOLOGY.-C. A. Kofoid and J. Grinnell, Editors.

This series contains the contributions from the Department of Zoology, from the

Marine Laboratory of the Scripps Institution for Blological Besearch, at Ia Jollo, California, and from the Caltfornia Musenm of Vertebrate Zoology in Berkeley.

Cited as Univ. Calif. Publ. Zool.

Volume 1, 1902-1905, 317 pages, with 28 plates

Volume 2, 1904-1906, xvil + 382 pages, with 19 plates

$\$ 3.50$

(ates

Volume 3, 1906-1907, 383 pages, with 23 plates .......................................................... \$3.50

Volame 4, 1907-1908, 400 pages, with 24 plates ............................................................ $\$ 3.50$

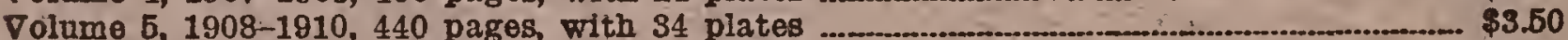

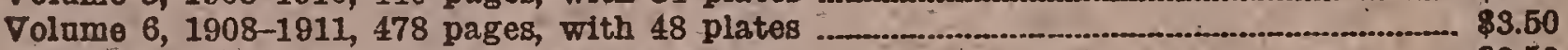

Volume 7, 1810-1912, 446 pages, with 12 plates ............ \$3.60

Volume 8, 1911, 357 pages, with 25 plates ............................................................. \$3.50

Volume 9, 1911-1912, 365 pages, with 24 plates $\ldots$

Volume 10, 1912-1913, 417 pages, with 10 plates .................................................... \$3.50

Volume 11, 1912-1914, 538 pages, with 26 plates .................................................

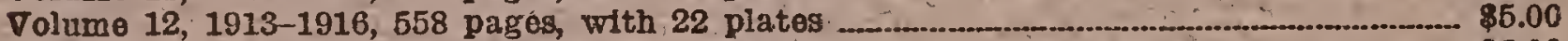

Volnme 13, 1914 1916, 529 pages, with 39 plates ......................................................... $\$ 5.00$

Volume 14, 1914 1918, 452 pages, with 60 plates ....................................................... 85.00

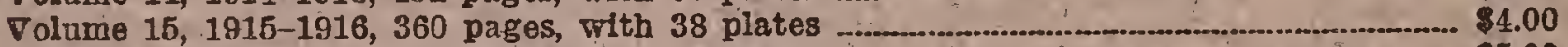

Volume 16, 1915-1917, 522 pages, with 46 plates $\ldots$

Volume 17, 1916-1918, 545 pages, with 24 plates ......................................................... $\$ 5.00$

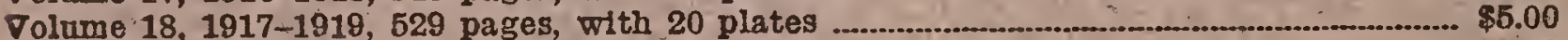

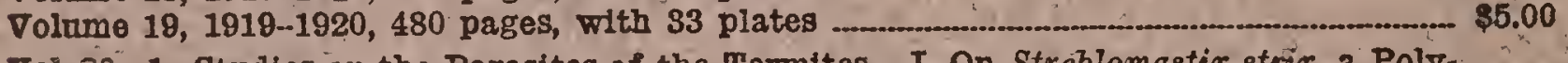

Vol. 20. 1. Studies on the Parasites of the Termites. I. On Streblomastix strix, a Poly mastigote Flagellate with a Iinear Plasmodial Phase, by Charles Atwood Kofoid and Olive Swezy. Pp. 1-20, plates 1-2, 1 figure in text. July, 1918

2. Studies on the Parasites of the Ternites. II. On Trichomitus termitidis, a Polymastigote Flagellate with a Highly Developed Neuromotor System, by Charles Atwood Kofold and Ollve Swezy. Pp. 21-40, plates 3-4, 2 figures in text. July, 1919

3. Studies on the Parasites of the Termates. III. On Trichonympha campanula sp. nov., by Charles Atwood Kofold and Olive Swezy. Pp. 41-98, plates 5-12, 4 figures in text. July, 1919

4. Studies on the Parasites of the Termites. IV. On Leidyopsis sphaerica gen. nov., sp. nov., by. Charles Atwood Kofold and Olive Swezy. Pp. 99-116, plates 13-14, 1 figure in text. July, 1919

5. On the Morphology and Mitosts of Chilomastix mesnili (Wenyon), a Common Flagellate of the Fuman Intestine, by Charles A. Kofold and Olive Swezy. Pp. 117-144, plates 15-17, 2 figures in text. April, 1920

6. A Critical Review of the Nomenclature of Human Intestinal Flagellates Cercomonas, Chilomastix, Trichomonas, and Giardia, by Charles A. Kofoid. Pp. 145-168, 9 figures in text. June, 1920

7. On the Free, Encysted, and Budding Stages of Councilmania lafleuri, a Para sitic Amoeba of the Human Intestine, by Charles Atwood Kofoid and Olive Swezy. Pp. 169-198, plates 18-22, 3 figures in text. June, 1921 .....

8. Mitosis and Fission in the Active and Encysted Phases of Giardia enterioa (Grassi) of Man, with a Discussion of the Method of Origin of Bllateral Symmetry in the Polymastigote Flagellates, by Charles A. Kofoid and Olive Swezy. Pp. 199-234, plates 23-26, 11 figures in text. March, 1922

9. The Mitcro-Injection of Paramaecium, by Chas. Wm. Rees. Pp. 235-242. April, 1922

10. On Balantidium coli (Malmsten) and Balantidium suis (sp. nov.), with an account of thetr nouromotor apparatus, by J. Daley McDonald. Pp. 243-300, plates 27, 28, 15 figures in text. May, 1922

11. Mitosis in Endamoeba dysenteriae in the Bono Marrow in Arthritis deformans, by Charles Atwood Kofoid and Olive Swezy. Pp. 301-\$07, 7 figures in text. 


$$
\begin{aligned}
& \text { Q K569 } \\
& .754 A 6
\end{aligned}
$$

SURFACE CATCHES OF MARINE DIATOMS AND DINOFLAGELLATES MADE BY U.S.S. PIONEER BETWEEN SAN DIEGO AND SEATTLE IN 1923 


\section{University of California Publications in Zoology}

Volume 26 , No. 12 , pp. 243-248, plate 25

Issued June 24, 1924

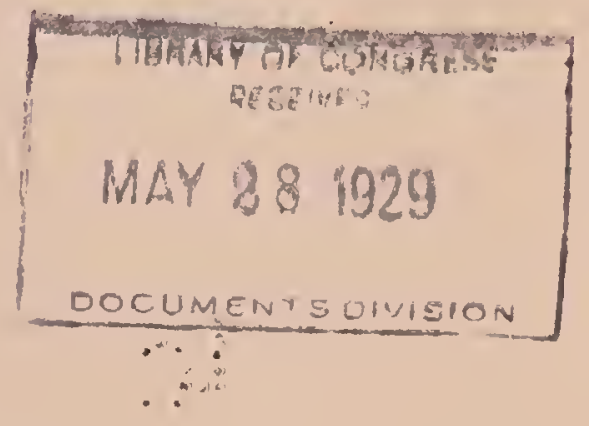




\title{
SURFACE CATCHES OF MARINE DIATOMS AND DINOFLAGELLATES MADE BY U.S.S. PIONEER BETWEEN SAN DIEGO AND SEATTLE IN 1923
}

\author{
$\mathrm{BY}$ \\ WINFRED EMORY ALLEN
}

(Contribution from Scripps Institution for Biological Research of the University of California)*

In the latter part of February, 1923, the United States Coast and Geodetic Survey Steamer Pioneer ended her winter work in the San Diego region and turned northward to prepare for summer work in Alaskan waters. On the northward trip, hourly collections were taken in the same way that they had been taken in the San Diego region (Allen, 1923). This series of collections was continuous to San Francisco. Collecting was resumed the first week in April and was again continuous as far as Seattle. It comprises a total of 119 catches from fifteen miles north of San Diego to a point near Seattle in Puget Sound.

On account of the uniform frequency of sampling" in this series, it has seemed desirable to make somewhat different designations of regional units from those formerly used (Allen, 1922). Although arbitrarily selectep, the limits of these regions have been largely determined by the more prominent coastal topographic features. (See map, fig. 1.) The position of the last eatch in each region has been taken as the distal boundary of that region.

In seven out of the eleven regions designated, at least a few diatoms were recorded for every catch. Of dinoflagellates, this was true in only two regions. In five regions, the largest catch of diatoms, and in four regions the average number of diatoms to the catch, were greater than 50,000 to the liter. In only two regions did catches of dinoflagellates reach 1000 to the liter, and in no region was the average to the catch so great as 1000 to the liter. (See table 1.)

Fifty-one species of diatoms, representing twenty-two genera, were recorded between San Diego and Scattle. The more important of

\footnotetext{
* Published by permission of Col. E. Lester Jones, Director of the U. S. Coast and Geodetic Survey.
} 


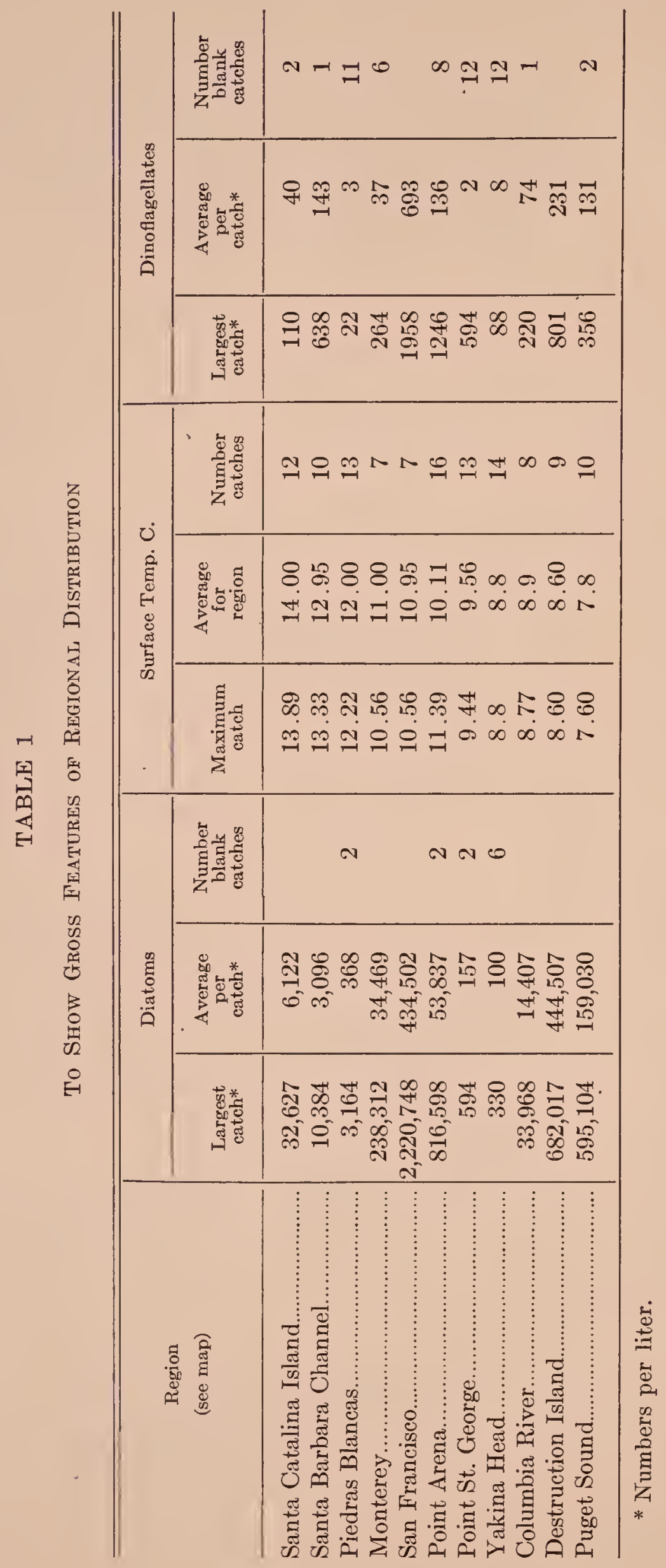


these had already been observed in the catches made by McEwen and Mortensen in 1920 (Allen, 1922). In the main, the same forms tended to prominence, although Nitzschia seriata Cl. was much less conspicuous than in the catches of 1920. Only in the Santa Barbara region did this species attain a place in the list of five most abundant forms.

Eight genera represented by ten species were found to be among the five most numerous forms in one or more regions. Of these, the most prominent numerically was Skeletonema costatum (Grev), which occupied first place in four regions out of the six in which it was. conspicuous. The genus Chaetoceras was second to Skeletonema only in numbers. In constancy of representation, it was, as usual, first. The specimens of this genus were mostly small and difficult to segregate, for which reasons the record is somewhat unsatisfactory. Small forms listed as Chaetoceras sp. were found in all regions. In addition, Chaetoceras debile $\mathrm{Cl}$. (sometimes including Ch. curvisetum $\mathrm{Cl}$.) and Chaetoceras scolopendra (Cl.) were notable in some regions. In this particular series, the genus Chaetoceras appears to be relatively much more prominent south of Monterey than in any region farther north.

The genus third in prominence in this series was Thalassiosira. Identification of the species was not fully satisfactory. Only two, Thalassiosira baltica (Grun) and Th. gravida Cl., were recorded although there may have been as many as four or five species present in some catches. This genus showed some prominence in the southerly regions, but it was so very abundant in the regions of Columbia River, Destruction Island, and Puget Sound as to suggest the idea that northerly conditions especially favor it.

Asterionella was more conspicuous than in most series and it was especially noticeable near San Francisco. Heretofore, only one species of this genus had been noticed, Asterionella japonica Cl., but in the course of study it became evident that another species, Asterionella kariana Grun, was also present. This species seems to be very fragile in many colonies, all the distal points of the cells being broken. This breakage probably led to more or less error in identification even after the presence of a second (and possibly a third) species was recognized, but it is very probable that $A$. japonica $\mathrm{Cl}$. is, in this series, more prominent in the southerly regions, while A. Kariana Grun is more prominent in the northerly regions.

Bacteriastrum, Grammatophora, and Eucampia are the other three genera which had representatives among the five most prominent 
forms in some regions, but there is nothing in the showing made by them which requires particular attention in this connection.

The catches of 1920 (Allen, 1922) did not give any strong indication that the species studied were peculiar to any particular section between San Diego and Puget Sound. It is therefore especially interesting to note that this more continuous series at a different season does give some evidence of restricted geographic range of some pelagic diatoms; e.g., the greater prominence of the genus Chaetoceras southerly, of Skeletonema medially, and of Thalassiosira northerly, and the possible difference in range of the two species of Asterionella, just mentioned.

As to geographic difference in quantity production, there are some interesting points. In 1920, the largest individual catches were made in the regions near to or north of Cape Mendocino. In this series, the largest catches were made in the San Francisco region, considerably south of that point (table 1 and fig. 1). Furthermore, the average production of catches in the San Francisco region is only slightly less than in the region of Destruction Island. On the other hand, only thirteen out of the sixty-five catches south of Cape Mendocino contained more than 10,000 to the liter while thirty-three of the fiftyfour catches north of Cape Mendocino exceeded that number. Superficially, this seems to be strong indication that productivity is greater in higher latitudes. It is, however, one thing to say that higher latitudes are places of greater production and quite another thing to say that they cause greater production in the sea. For example, they may merely mark the region in which land drainage most favorably influences marine productivity. The showing in the San Francisco region makes it desirable to delay the statement of a conclusion until we are sure that latitude exerts a determining influence instead of merely accompanying such an influence. (Allen, 1922, p. 143.)

Although it was not possible to make hydrographic observations to accompany this series of collections, records of temperatures at times of collecting were regularly made. These temperature records are partly summarized in the middle columns of table 1 . As might be expected, this summary shows a steady lowering of temperatures toward the north. Six out of eleven maximum catches were taken in temperatures slightly below the average for the region, but there is no special significance in this isolated fact. The fact that the two most consistently productive regions were those of lowest temperature while that of largest production was of a somewhat higher temperature 
is important because it adds to the evidence that, under ordinary circumstances, temperature is not a directly determining factor in productivity of marine diatoms.

In considering the evidence of productivity in this series of catches, it should be remembered that the southerly regions were traversed in late February (not usually a highly productive month), while the northerly regions were traversed in April (in some years the most productive month). For that reason, direct comparison of areas south of San Franciseo with areas north of that point is rather unsatisfactory. So far as we really know, the southerly sections may also have been heavily productive in April. Still, it is not probable that the relative conditions of temperature were very different in the two months, since it is known that southerly sections get some of their coldest water in March and early April.

At this time of year, the greatest change in any single environmental condition is supposed to be in the effect of the sun's rays. There are excellent general and theoretic reasons for connecting vernal increase in productivity with solar influence, but, unfortunately, that is one factor concerning which marine researches are almost entirely lacking.

Comparison of productivity of regions in this series with that of those in the 1920 series shows that the Destruction Island and San Francisco regions were highly productive in all three cases (McEwen in summer, Mortensen through fall, and the Pioneer in early spring). The Point St. George region was poorly productive in all cases while the Yakina Head region was most productive in Mortensen's catches and very poor in MeEwen's and those of the Pioneer. Thus we find additional evidence that some regions may be highly variable in productivity according to season or circumstance. On the other hand, it seems probable that some regions, e.g., Destruction Island, may always show relatively high productivity as compared with other regions.

It is not possible at present to make a conclusive statement essentially different from that concerning the 1920 series (Allen, 1922). This is, however, an appropriate place to emphasize the fact that, with such vessels as the Pioneer, plankton collecting of very high value can be done, and that the spirit of coöperation shown by the officers and men of the U.S.S. Pioneer is exceedingly encouraging for more rapid and effective advances in oceanic research. The enthusiasm of the administrative officers of the U. S. Coast and Geodetic Survey in Washington is also encouraging and deserving of high commendation. 


\section{LITERATURE CITED}

Allen, W. E.

1922. Observations on surface distribution of marine diatoms between San Diego and Seattle. Ecology, 3, 140-145.

1923. Statistical studies of marine diatoms of the San Diego region collected by U.S.S. Pioneer in midwinter 1923. Univ. Calif. Publ. Zool., 22, $445-448$. 


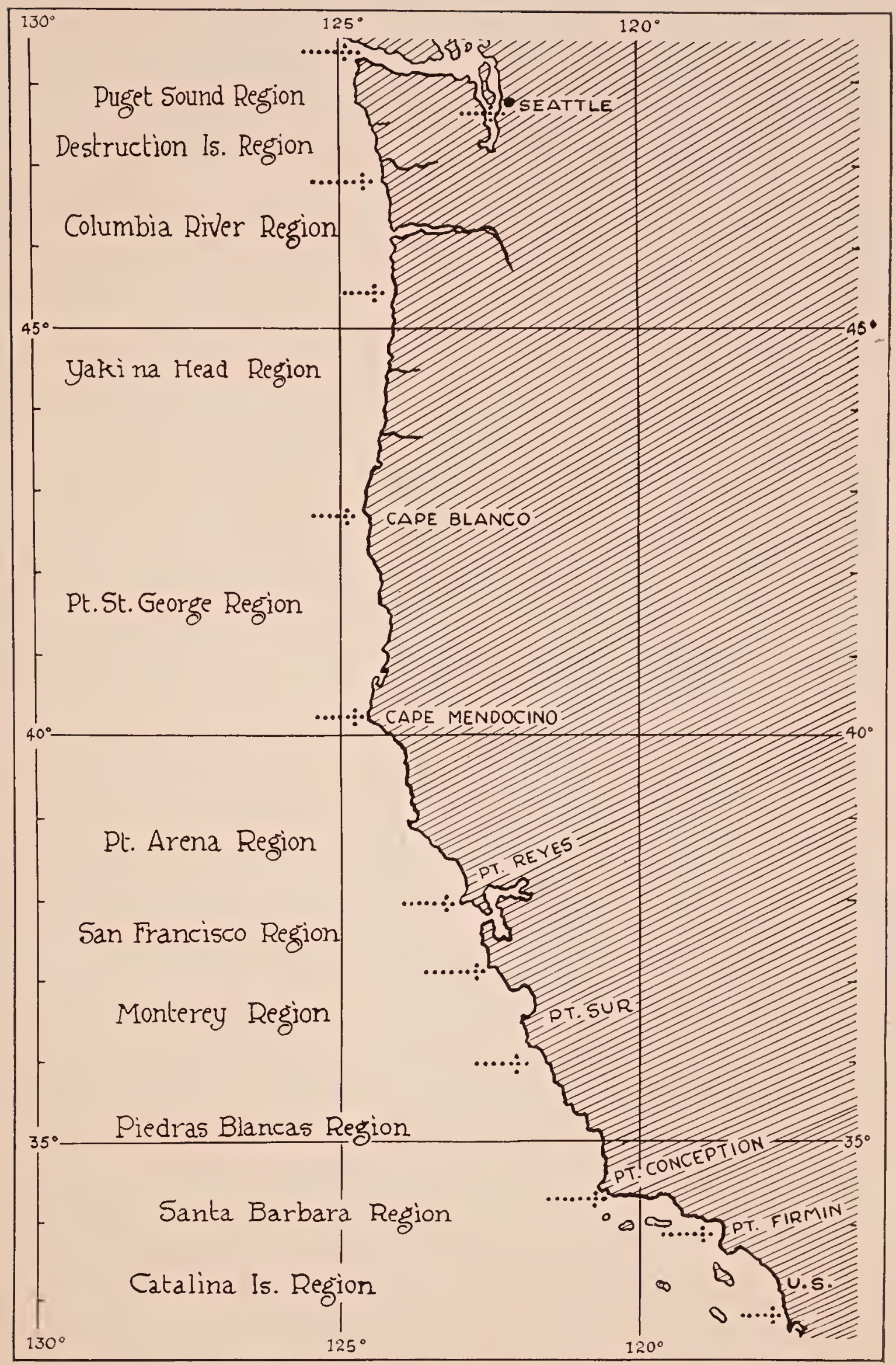

Fig. 1. Map Diagram of Pacific Coast of United States. Regional Boundaries indicated by dotted lines. 

UNIVERSITY OF CALIFORNIA PUBLICATIONS-(Continued)

12. Endamoeba dysenterice in the Iymph Glands of Man in Hodgkin's Disease, by Charles A. Kofold, Iuther M. Boyers, M.D., and Olive Swezy. Pp. 309. 312, 4 figures in text.

Nos, 11 and 12 in one cover. April, 1922

13. Mitosis in the Encysted Stages of Endamoeba coli (Loesch), by Olive Swezy. Pp. 313-332, plates 29-31. May, 1922

14. The Neuromotor Apparatus of Paramaecium, by Charles William Rees. Pp. 333-364; plates 32-36, 5 figures in text. November, 1922.

15. A Comparison of the Cysts of Endamaeba coli and Councilmania lafleuri in Congo Red, by Nathaniel Bercovitz, M.D. Pp. 365-371. February, 1923.

16. On the Morphology and Behavior of Pentatrichomonas ardin delteili (Derrieu and Raynaud), by Charles Atwood Kofold and Olive Swezy. Pp. 373-390, plate 37, 1 figure in text. August, 1923

17. The Pseudopodial Mothod of Feeding by Trichonymphid Flagellates Para sitic in Wood-eating Termites, by Olive Swezy. Pp. 391-400, 14 figs, in text. August, 1923

18. Methods of Obtaining Amoeba-free Rats for Experimental Infection with Intestinal Amoebae, by John F. Kessel. Pp. 401-408.

19. Experimental Infection of Rats and Mice with the Common Intestinal Amoebae of Man, by John F. Kessel. Pp. 409-430, plates 38-39.

Nos. 18 and 19 in one cover. October, 1923

20. On the Genus Councilmania, Budding Intestinal Amoebae Parasitic in Man and Rodents, by Charles A. Kofoid, Olive Swezy, and John F. Kessel. Pp. 431-445, 19 figures in text. October, 1923

21. Morphology and Binary Fission of Menoidium incurvum (Fros.) Klobs, by Richard P. Fiall. Pp. 447-476, plates $40-41,2$ figures in text. Navember, 1923

22. A Skin Reaction to Extracts of Leishmania tropica and Leishmania in. fantum, by Edna Hannibal Wagener. Pp. 477-488, plate 42. December, 1923

23. The Distinguishing Characteristics of the Parasitic Amoebae of Culture Rats and Mice, by John F. Késsel. Pp. 489-544, plates 43-48, 3 figures in text. February, 1924

Wol. 21. 1. A Revision of the Microtus californicus Group of Meadow Mice, by Remington Kellogg. Pp. 1-42, 1 figure in text. December, 1918

2. Five New Five-toed Kangaroo Rats from Califormia, by Joseph Grinnoll. Pp. 43-47. March, 1919

3. Notes on tho Natural History of the Bushy-tailed Wood Rats of Calffornia, by Joseph Dixon. Pp. 49-74, plates 1-3, 3 figures in text. Decomber, 1919

4. Revision of the Avian Genus Passerella, with Special Reference to the Distribution and Migration of the Races in California, by H. S. Swarth. Pp. 75-224, plates 4-7, 30 figures in text. September, 1920

5. A Study of the California Jumping Mice of the Genus Zapus, by A. Brazier Howell. 'Pp. 225-238, I figure in text. May, 1920

6. T'́o New Rodents (Genera Thomomys and Marmota) from the Easterm Border of Califormia, by Joseph Grinnell. Pp. 239-244, 6 figures in text. November, 1921

7. A Study of the Californian Forms of the Microtus montanus Group of Meadow Mice, by Remington. Kellogg. Pp. 245-274, 25 figures in text.

8. A Synopsis of the Microtus mordax Group of Meadow Mice in California, by Remington Kellogg. Pp. 275-302, plate 8, 29 figures in text. Nos. 7 and 8 in one cover. April, 1922

9. Behavior of the Leaf-nosed Snake, Phyllorhynchus decurtatus, by Sarah Rogers Atsatt. Pp. 303-312. February, 1923

10. A Systematic List of the Mammals of Califormia, by Joseph Grinnell. Pp. 313-324. January, 1923.

11. The Systematic Status of the Mountain Lion of Calfornia, by Joseph Grinnell and Joseph Dixon. Pp. 325-332, plates 9-10. April, 1923.

12. New Subspecies of Birds from Patagonia, by Alexander Wetmors. Pp. 333-337: June, 1923

13. Revision of the Genus Lynx in California, by Joseph Grinnell and Joseph Dixon. Pp. 339-354, plate 11, 1 figure in text. Janúary, 1924

Fol. 22. 1. A Quantitative and Statistical Study of the Plankton of the San Joaquin River and Its Irlbutaries in and near Stockton, Callfornia, in 1913, by Winfred Emory Allen. Pp. 1-292, plates 1-12, 1 figure in toxt. June, 1920. $\$ 3.00$

2. Variations in the Shell of Teredo navalis in San Francisco Bay, by Robert Cunningham Miller. Pp. 293-328, plates 13-17, 6 flgures in text. Novem-

8. Quantitative Studies on Marine Phytoplankton at La Jolla in 1919, by Winfred Emory Allen. Pp. 329-347, 2 figures in text. November, 1922 


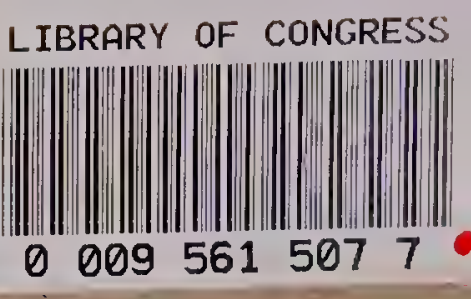

\section{UNIVERSITY OF CAIIFORNIA PUBLICATIONS-(Continued)}

4. On the Fffect of Low Salinlty on Teredo navalis, by Farold Francis Blum. Pp. 349-368, 4. figures in text., December, 1922

b. Quantitative Studies on Inshore Marine Diatoms and Dinoflagellates of Southern California in 1920, by Winfred Emory Allen. Pp. 369-378, 1 figure in text.

6. Stylarioides papillosa, sp. nov., a New Annelid from the San Diego Reglon, by Christine E. Essenberg. Pp. 379-381, 8 figures in text.

Nos. 5 and 6 in one cover. December, 1922

7. The Digestion of Wood by Teredo navalis, by Walter $\mathbf{I}$. Dore and Robert C. Miller. Pp. 383-400, plate 18. February, 1923

8. Variations in the Pallets of Teredo navalis in San Francisco Bay, by Robert Cunningham Miller. Pp. 401-414, plates 19-20. February, 1923

9. Some Tide-Water Collections of Marine Diatoms taken at Half-Hour Intervals near San Diego, Callifornia, by Winfred E. Allen. Pp. 413-416, 1 figure in text. June, 1923

10. Preliminary Statistical Report on the Occurrence of Marine Copepoda in the Plankton at La Jolla, California, by Calvin O. Esterly. Pp. 417-433. June, 1923

11. Studies on Marine Diatoms and Dinoflagellates Caught by Ald of the Kofoid Bucket in 1922, by Winfred Emory Allen. Pp. 435-445, 5 figures in text. October, 1923

12. Statistical Studies of Marine Diatoms of the San Diego Region Collected by U.S.S. Pioneer in Midwinter of 1923, by Winfred Emory Allen. Pp. 445-448. November, 1923

13. Iife Cycle of Oithona nana Reared Experimentally, by Helen E. Murphy. Pp. 449-454, 5 figures in text. November, 1923 ..................................

14. Morphology of the Digestive Tract of Teredo navalis, by Edgar Locke Iazier. Pp. 455-474, plates, 21-24. February, 1924.

Vol. 23. The Marine Decapod Crustacea of California, by Waldo I. Schmitt. Pp. 1-470, plates 1-50, 165 figures in text. May, 1921

Val.24. 1. A Geographical Study of the Kangaroo Rats of Califormia, by Joseph Grinnell. Pp. 1-124, plates 1-7, 24 figures in text. June, 1922

2. Birds and Mammals of the Stikine River Region of Northern British Columbia and Southeastern Alaska, by H. 8. Swarth. Pp. 125-314, plate 8, 34 figures in text. June, 1922

3. Birds and Mammals of the Skeena River Region of Northern British Columbia, by Harry $\mathbf{S}$. Swarth. Pp. 315-394, plates 9-11, 1 figure in text. January, 1924

Vol. 25. A Bibliography of Eugenics, by Samuel J. Holmes. Pp. 1-514. January, 1924

Vol.26. 1. On the Family of Achiridae or Broad-Soles, with description of a new species, Achirus barnharti, from California, by David Starr Jordan. Pp. 1-14, plate 1. December, 1923

2. A Precipitin Test in Experimental Amoebic Dysentery in Cats, by Edna Hannibal Wagener. Pp. 15-20, plate 2. January, 1924

3. On the Distinctions between Endamoeba coli and Councilmania lafleuri, by Charles A. Kofoid, Olive Swezy, and John F. Kessel. Pp. 21-39, 24 figures in text. January, 1924

4. The Boring Mechanism of Teredo, by Robert Cunningham Miller. Pp. 41-

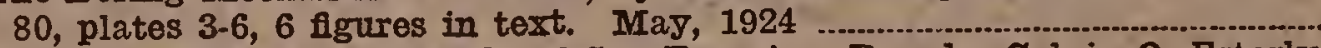

5. The Free-swimming Conepoda of San Francisco Bay, by Calvin 0. Esterly. Pp. 81-129, 16 figures in text. May, 1924

6. Fatal Effects of the Removal of the Micronucleus in Euplotes, by Charles $\nabla$. Taylor and William P. Farber. Pp. 131-144, plate 7. May, 1924...............

7. Wood-boring Mollusks from the Hawaiian, Samoan, and Philippine Islands, by Robert Cunningham Miller. Pp. 145-158, plates 8-11.

8. Wood-boring Crustacea from Hawaii and Samoa, by Robert Cunningham Miller. Pp. 159-164, plates 12-13.

Nos. 7 and 8 in one cover. May, 1924

9. The Cytology of Endamoeba gingivalis (Gros) Brumpt Compared with that of $E$. dysenteriae with Special Reference to the Determination of the Amoebas in Bone Marrow in Arthritis deformans of Ely's Second Type, by Charles A. Kofoid and Olive Swezy. Pp. 165-198, plates 14-18, 1 figure in text. June, 1924

10. Morphology and Mitosis of Dinenympha fimbriata sp. nov., by Harold Kirby, Jr. Pp. 199-220, plates 19-22. June, 1924

11. Karyamoeba falcata, a New Amoeba from the Human Intestinal Tract, by Charles A. Kofoid and Olive Swezy. Pp. 221-242, plates 23-24, 2 figures in text. June, 1924

12. Surface Catches of Marine Diatoms and Dinoflagellates made in 1923 by U.S.S. Pioneer between San Diego and Seattle, by Winfred Emory Allen. Pp. 243-248, plate 25. June, 1924 